УДК: $7.033 .2 \ldots 1$

ББК: 85.13

A43

DOI:10.18688/aa166-2-12

Fanny Vitto

\title{
Swinging Thuribles in Early Byzantine Churches in the Holy Land
}

Swinging thuribles producing fragrant smoke are commonplace in the Eastern Orthodox, Oriental Orthodox, Armenian, and Roman Catholic Churches. The use of incense, though, predates Christianity by thousands of years. The practice of incense burning during religious ceremonies was customary for most ancient civilizations around the Mediterranean. It originated in the Near East, doubtlessly because its ingredients, frankincense and spices, were indigenous to this area. Frankincense is an aromatic resin obtained from the Boswellia sacra tree which grew mainly in southern Arabia and southern Nubia. Isaiah (Isaiah 60:6) speaks of the caravans of camels from Midian and Sheba carrying gold and frankincense. Incense was a greatly valued commodity in the ancient times. It is quite significant that frankincense ( $\lambda i ß a v o \varsigma)$ was one of the three gifts the Magi offered to infant Jesus (Matthew 2:11).

In antiquity, incense was burned in various vessels including high clay stands, tripods with holes and horned altars. The Old Testament contains numerous references to the use of incense in Ancient Israel $[9 ; 15 ; 23]$. There were two terms for incense used in Hebrew: qetoret (a burning mixture of spices) and levonah (meaning white, i.e., frankincense which is one of the ingredients in qetoret). In the Temple of Jerusalem incense was burned by the High Priest in the Holy of Holies. On the Day of Atonement, the smoke of incense (qetoret sammim) symbolically carried men's prayers to God in order to obtain forgiveness for their sins.

In the pre-Nicene Church, incense was not used, because it was associated with heathen divinities. Among Christians thurification was allowed only after the Pax Constantiniana, when Christianity became the official religion of the Roman Empire [6, pp. 567-573; 8, pp. 425-430]. In the East Syrian Church, the Old Testament idea of incense burning as atonement for sins was adopted as early as A.D. 363. In the Carmina Nisibena [1, p. 55 (17:4, 6-7)], Saint Ephraim addressing Abraham (the bishop of Nisibis) declares: "Your burning of incense is our propitiation. Praised be God who has honoured your offering". St. Ephraim is often represented holding a censer. The use of incense in an Antioch church is mentioned in a Homily on the Gospel of Matthew by John Chrysostom [21: col. 781] dated to the late $4^{\text {th }}$ century. At about the same time (in A. D. 381), the western European pilgrim Egeria [11 (24:10); 34, pp. 65, 83, 125], describing the liturgy in the Church of the Anastasis in Jerusalem, writes that "thymiateria were brought into the cave of the Anastasis so that the whole Basilica of the Anastasis were filled with the smell". The thymiateria described by Egeria and John Chrysostom at the end of the $4^{\text {th }}$ century A. D. were, most likely, table censers and not swinging thuribles. Indeed, the latter, bowls made of bronze and suspended on three chains did not appear in the Eastern Mediterra- 
nean before the $6^{\text {th }}$ century A.D. This is evident from the discovery of such vessels in well-dated contexts and their representation on mosaic floors dating from the $6^{\text {th }}$ century onwards.

All the early Byzantine swinging thuribles discovered in the Eastern Mediterranean are open-type vessels (without a lid). They consist of a small plain or simply decorated bowl (diam. 7.5-10 cm; height 3.5-6 cm) made of bronze. The thuribles were suspended by three chains attached to the rim of the bowl by means of handles and joined at the top by a ring, or a cross, or a hook. A number of variants existed: circular or hexagonal, with or without feet. Only a few thuribles were just plain circular bowls with a low ringed base and no legs, e.g. those found at Shoham [17, p. 102 (219.c)] and Yatir/Iethira [17, p. 102, (219.g)]. The majority of the thuribles, discovered on the sites of Palaestina Prima and Secunda located to the west of the River Jordan, are circular bowls decorated with vertical fluting on the exterior with a low ring base and no legs, e.g. at Jerusalem [17, p. 102, (219.a)], Jericho [17, p. 98], Beth Shean (Scythopolis) [17, p. 102, (219.f)], Horbat Bata (Carmiel) in Galilee (Ill. 21) [32; 33] and Sussita (Hippos) [22, pp. 49-50, fig. 13C; 5, pp. 31-32, fig. 17C]. Similar examples, also decorated with vertical fluting, which are kept in various museums such as Cairo, Vienna, Berlin, Paris and Saint Petersburg, are said to come from Egyptian sites [2, Nos. 249-252]. Hexagonal three-legged bowls were found in excavations at Beth Shean/Scythopolis [10, Pl. XXXVIII.24], [17, p. 102 (219.h)] and Khalde in Lebanon [7, p. 120, Pl. LXXIX.12]. This type was represented on some mosaic pavements of churches in present-day Jordan (e.g. at Jerash (Gerasa), in the Chapel of Elias, Maria and Soreg dating to the $6^{\text {th }}$ century A.D., a cleric named Elias is depicted holding a hexagonal thurible with three feet [24, p. 296, fig. 572; 26, pl. 45]; and in the Church of Saint Cosmas and Damianus, a mosaic dated to A.D. 533 portrays the paramonarius Theodoros holding a hexagonal three-legged thurible, containing burning charcoal represented by red tesserae (Ill. 22) [24, p. 276, fig. 507].

Swinging thuribles also appear on the wall mosaics of Byzantine churches in Ravenna. In the apse of the Church of San Vitale, on a panel dating to the $6^{\text {th }}$ century, for example, there is a depiction of a deacon standing to the left of the Emperor Justinian and holding a circular flat based three-legged thurible, which contains burning charcoal represented by red tesserae [4, p. 136]; and in the Church of San Apollinaire in Classe, on a panel dating to the $7^{\text {th }}$ century A. D. that represents the emperor Constantine IV granting privilege to the Ravennate church, a cleric is holding a circular thurible with three legs, containing burning charcoal [4, p. 159]. In order to produce smoke, it is very important to hold the thurible correctly, and all the above mosaics depict a thurifer holding the thurible in the right hand, while the index finger is inserted into a ring that connects the three chains of the thurible.

Only a few thuribles were discovered in controlled excavations. Most of them are kept in museums, and we do not know where exactly in the church they were found. The few examples discovered in the course of excavations (at Horbat Bata (Carmiel), Sussita (Hippos) and Beth Shean (Scythopolis) show that, when not in use, the thurible was stored in an annex-room, the diaconicon or sacristy. The same is true for the thurible discovered in the sacristy of a church in Nubia, at Nag esh-Sheima (Sayala) [27, p. 132]. The sacristy was a service-room for the deacon, where he stored church equipment for the liturgy and prepared the Eucharist offerings. This room played an essential role in the smooth functioning of the liturgy and had to be directly accessible from the church [20]. 
Several scholars have tried to answer the question: when was the thurible first brought into a church? Was it in the course of the Little Entrance, when the deacon brings the Gospel and presents it to the priest, or was it in the course of the Great Entrance, during which Eucharistic bread and wine are brought from the place of preparation to the place of offering on the altar $[19, \text { pp. 138-176] }]^{1}$ ?

Taft [30, p. 154] is of the opinion that in the early Byzantine tradition, the thurification was performed during the Great Entrance, and that it was not an act of propitiation, like that of the Old Testament and the Syrian tradition, but an act of reverence.

According to most scholars, the Great Entrance rite was introduced to the liturgy in the second half of the $6^{\text {th }}$ century, about the time of Justin II (565-578 A.D.). It is interesting to note that swinging thuribles also seem to appear at about the same time; and the fact that the rooms where the thuribles were stored had direct access to the church may confirm the claim that the procession or the 'Entrance' took its start in the diaconicon.

From the foregoing it follows that, firstly, all the thuribles discovered in present-day Jordan, Israel and Lebanon are plain vessels, with no decoration except for some vertical fluting. However, in many museums, we see thuribles richly decorated with scenes from the Life of Jesus or other Christian themes. They are often described as originating in Syria-Palestine. In most cases, they were bought or donated and their place of discovery is unknown. A limited number of studies have been devoted to these decorated thuribles and the dates attributed by modern scholars to them range between the $5^{\text {th }}$ and the $17^{\text {th }}$ century $[25 ; 14 ; 16 ; 2$, no. $271 ; 3]$. So far, none of these decorated censers has been found in the course of excavation in a $6^{\text {th }}$ or $7^{\text {th }}$ century context in the Holy Land, strongly suggesting that they are of a later period.

Secondly, all the swinging thuribles we have seen are open thuribles with no top cover. A few square censers with a lid have been found in excavations in $6^{\text {th }}-7^{\text {th }}$ century contexts, but so far none in churches. One was discovered in a Samaritan complex near Nablus [18, p. 175, fig. 15] and another one in a Jewish context at Beth Shean/Scythopolis [31, p. 67]. They have only one chain attached to the cover which served to lift the lid. It indicates that they were not intended to be swung but to stand on a surface. In the Catholic Church, swinging thuribles were covered by a lid from a relatively early period $\left(10^{\text {th }}\right.$ century?). The presence of a lid allowed a thurible to be swung with greater amplitude and without spilling incense. One of the most famous thuribles in the West is the Huge Botafumeiro in the Cathedral of Santiago of Compostela located in northwestern Spain. Suspended from the ceiling of the cathedral by a pulley mechanism, the current thurible weighs $80 \mathrm{~kg}$ and is $1.60 \mathrm{~m}$ high. It swings in the transept of the church in a $65 \mathrm{~m}$ arc and needs eight men to activate it. In $12^{\text {th }}$ century written sources, it is called the Turibulum Magnum, suggesting that it was already quite large.

Unlike the Catholic Church, the Eastern Church continued the use of swinging thuribles without a cover for many centuries. At Novgorod the Great, in the Church of the Transfigura-

In the Church of San Vitale in Ravenna, the wall mosaic represents the Emperor Justinian and a deacon carrying a thurible. Scholars, such as von Simson [28, pp. 29-30] and Stričevič [19], have claimed that it represents the 'Great Entrance', when the Eucharistic bread and wine are brought, but André Grabar [12, pp. 106-107; 13] did not concur with their interpretation and explained that this scene clearly represents 'the Little Entrance?. 
tion of Our Savior, there is a fresco dating to 1380 depicting a swinging thurible without a lid (Ill. 23). A scene representing the Dormition of Saint Nicholas of Zaraysk dated to the mid$16^{\text {th }}$ century also shows an open thurible which is similar to those discovered in $6^{\text {th }}$-century churches of the Holy Land.

Title. Swinging Thuribles in Early Byzantine Churches in the Holy Land.

Author. Fanny Vitto - field and research archaeologist. Israel Antiquities Authority, POB 586, Jerusalem 91004, Israel. vitfan@hotmail.com

Abstract. The use of swinging thuribles for incense burning is a familiar scene in the Eastern Orthodox and Roman Catholic churches. The practice of incense burning in religious ceremonies predates Christianity by thousands of years, and the Old Testament, for example, contains numerous references to it. As early as the $4^{\text {th }}$ century A.D., literary sources described the practice of burning incense during the church services in the Holy Land. Several examples of bronze bowls with no lid, suspended by three chains, have been discovered in Early Byzantine churches in the Eastern Mediterranean or are depicted on mosaics of contemporaneous churches in Ravenna and in present-day Jordan. Unlike the Catholic Church, the Eastern Church continued using uncovered swinging thuribles for many centuries.

Keywords: swinging thuribles; frankincense; Early Byzantine churches; Holy Land.

Название статьи. Кадила на цепях, использовавшиеся в ранневизантийских церквах в Святой земле.

Сведения об авторе: Витто Фанни - археолог, исследователь. Управление древностей Израиля. П/я 586, Иерусалим 91004, Израиль. vitfan@hotmail.com

Аннотация. Кадильницы на цепях, в которых курится приятно пахнущий ладан, - хорошо известный элемент богослужения православной и римской католической церквей. Однако каждение в богослужении намного старше христианства, и Ветхий Завет неоднократно упоминает этот обычай. Уже в IV в. письменные источники описывают каждение на богослужениях в Святой земле. Несколько бронзовых кадильниц без крышки с тремя цепями были найдены в ранневизантийских церквах в Восточном Средиземноморье. В восточнохристианском богослужении использование таких кадильниц без крышек продолжалось и далее на протяжении многих столетий.

Ключевые слова: кадило; ладан; ранневизантийские церкви; Святая земля

\section{References}

1. Beck E. (ed.) Carmina Nisibena. Corpus Scriptorum Christianorum Orientalium, vol. 219: Scriptores Syri, vol. 93. Louvain, Peeters Publ., 1961. 112 p.

2. Bénazeth D. Catalogue géneral du Musée copte du Caire 1: Objets en metal. Mémoires de l'Institut français d'archéologie orientale, vol. 119. Cairo, 2001. 451 p. (in French).

3. Billod-Lochman C. Un encensoir oriental dans les Grisons? Helvetica Archaeologica, 1989, no. 20, pp. 123-137 (in French).

4. Bovini G. The Churches of Ravenna. Novara, Istituto geografico De Agostini Publ., 1960. 164 p.

5. Burdajewicz M.; Młynarczyk J. Elements of the Liturgical Furniture in an $8^{\text {th }}$-Century Church (NWC) in Hippos (Susita), Israel. Series Byzantina, 2006, no. 4, pp. 9-37.

6. Caseau B. Objects in Churches: The Testimony of Inventories. Objects in Contexts, Objects in Use: Material Spatiality in Late Antiquity (Late Antiquity Archaeology, vol. 5). Leiden - Boston, Brill Publ., 2007, pp. 566-579.

7. Chéhab M. H. Mosaïques du Liban: Texte. Bulletin du Musée de Beyrouth, vol. 14-15. Paris, Maisonneuve Publ., 1957. 193 p. (in French).

8. Dix G. The Shape of the Liturgy. London, Dacre Press Publ., 1945. 764 p.

9. Felix J. Incense and Perfumes. Encyclopaedia Judaica, vol. 8. Jerusalem, Keter Publ., 1971, pp. 1310-1316.

10. Fitzgerald G. M. Beth-Shan Excavations 1921-1923: The Arab and Byzantine Levels. Philadelphia, University of Pennsylvania Press Publ., 1931. 64 p.

11. Franceschini E.; Weber R. (eds.) Itinerarium Egeriae. Itineraria et alia geographica [Corpus Christianorum, Series Latina 175]. Turnhout, Brépols Publ., 1965, pp. 27-90 (in Latin).

12. Grabar A. L'empereur dans l'art byzantin. Paris, Les Belles Lettres Publ., 1936. 296 p. (in French). 
13. Grabar A. Quel est le sens de l'offrande de Justinien et de Théodora sur les mosaïques de Saint-Vital? Felix Ravenna, 1960, no. 81, pp. 63-77 (in French).

14. Hamilton R. W. Thuribles: Ancient or Modern? Iraq, 1974, no. 36, pp. 53-75.

15. Haran M. The Uses of Incense in the Ancient Israelite Ritual. Vetus Testamentum, 1960, no. 10, pp. 113129.

16. Harrak A. The Incense Burner of Takrit: An Iconographical Analysis. Eastern Christian Art, 2006, no. 3, pp. 47-52.

17. Israeli Y.; Mevorah D. Cradle of Christianity. Jerusalem, Israel Museum Publ., 2000. 232 p.

18. Magen Y. Qedumim - A Samaritan Site of the Roman-Byzantine Period. Early Christianity in Context: Monuments and Documents (SBF Collectio Maior 38). Jerusalem, Franciscan Printing Press Publ., 1993, pp. 167-180.

19. Matthews T. F. The Early Churches of Constantinople: Architecture and Liturgy. London, University Park, Pennsylvania State University Press Publ., 1971. 194 p.

20. Michel V. Furniture, Fixtures, and Fittings in Churches: Archaeological Evidence from Palestine $\left(4^{\text {th }}-\right.$ $8^{\text {th }}$ c.) and the Role of the Diakonikon. Objects in Contexts, Objects in Use: Material Spatiality in Late Antiquity (Late Antiquity Archaeology, vol. 5). Leiden - Boston, Brill Publ., 2007, pp. 581-606.

21. Migne J.-P. (ed.) John Chrysostom. In Matthaeum Homilia 89. Patrologiae cursus completes. Series graeca, vol. 58. Paris, 1862, cols. 781-788 (in Greek and Latin).

22. Młynarczyk J.; Burdajewicz M. North-West Church in Hippos (Sussita), Israel: Five Years of Archaeological Research (2000-2004). Eastern Christian Art in Its Late Antique and Islamic Contexts, 2005, no. 2, pp. 39-58.

23. Nielsen K. Incense in Ancient Israel (Supplements to Vetus Testamentum XXXVIII). Leiden, Brill Publ., 1986. $147 \mathrm{p}$.

24. Piccirillo M. The Mosaics of Jordan. Amman, American Center of Oriental Research Publ., 1992. 383 p.

25. Richter-Siebels I. Die palästinensischen Weihrauchgefässe mit Reliefszenen aus dem Leben Christi, 2 vols. Ph. D. diss. Berlin, Freie Universität Berlin, 1990 (in German).

26. Saller S. J.; Bagatti B. The Town of Nebo (Khirbet el-Mekhayyat). Jerusalem, Publications of the Studium Biblicum Franciscanum Publ., 1949. 302 p.

27. Schienerl P. W. The Church within the Christian Fortress at Nag esh-Sheima (Sayala-Nubia). Bulletin de la Société archéologique copte, 1975, no. 21, pp. 125-133.

28. Simson O. G. von. Sacred Fortress: Byzantine Art and Statecraft in Ravenna. Princeton, Princeton University Press Publ., 1948. 149 p.

29. Stričević G. Iconografia dei mosaici imperiali a San Vitale. Felix Ravenna, 1959, vol. 80, pp. 5-27 (in Italian).

30. Taft R. F. The Great Entrance: A History of the Transfer of Gifts and Other Pre-anaphoral Rites of the Liturgy of St. John Chrysostom. Rome, Pontificium Institutum Studiorum Orientalium Publ., 1975. 490 p.

31. Tzori N. Bronze Utensils from Byzantine Beth Shean. Qadmoniot, 1970, no. 10, pp. 67-68 (in Hebrew).

32. Vitto F. Horvat Bata (Karmiel) - 1984. Excavations and Surveys in Israel, 1984, no. 3, pp. 7-8.

33. Vitto F. A Byzantine Church Compound and an Oil Plant at Bat as-Sikh (Horbat Bata), Carmiel. Atiqot (in press).

34. Wilkinson J. Egeria's Travels to the Holy Land. Jerusalem - Warminster, Ariel Publ.; Aris \& Philips Publ., 1981. 354 p. 


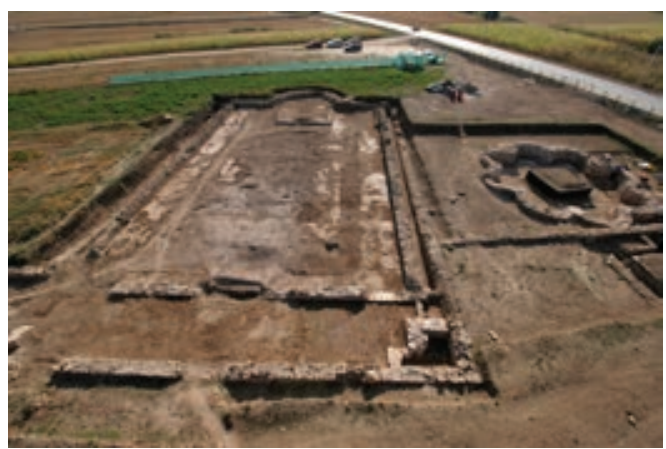

Ill. 18. Aerial photograph of the church. Ulpiana, Kosovo. Photo by H. Çetinkaya

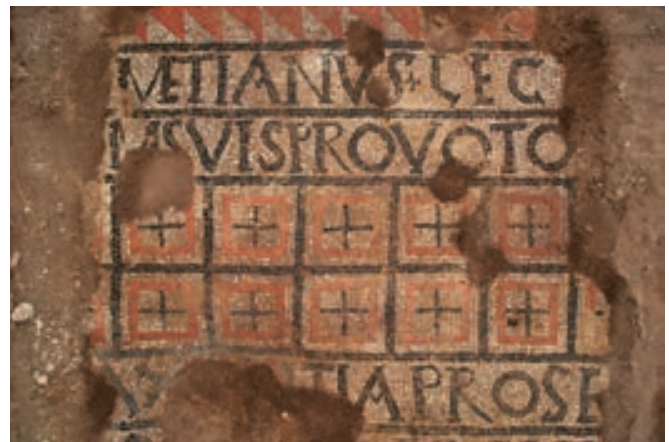

Ill. 20. Mosaics with crosses. Ulpiana, Kosovo. Photo by H. Çetinkaya
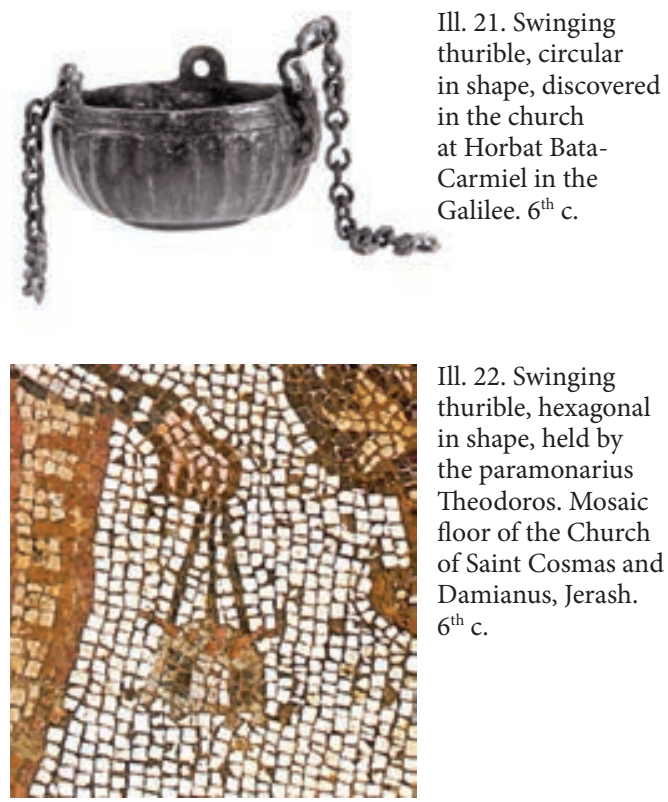

Ill. 22. Swinging thurible, hexagonal in shape, held by the paramonarius Theodoros. Mosaic floor of the Church of Saint Cosmas and Damianus, Jerash. $6^{\text {th }} \mathrm{c}$.

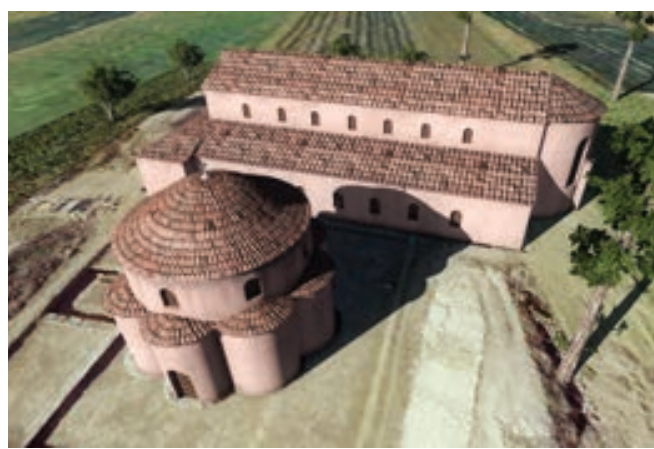

Ill. 19. Probable look of church and baptistery. Ulpiana, Kosovo. Author: T. Öner

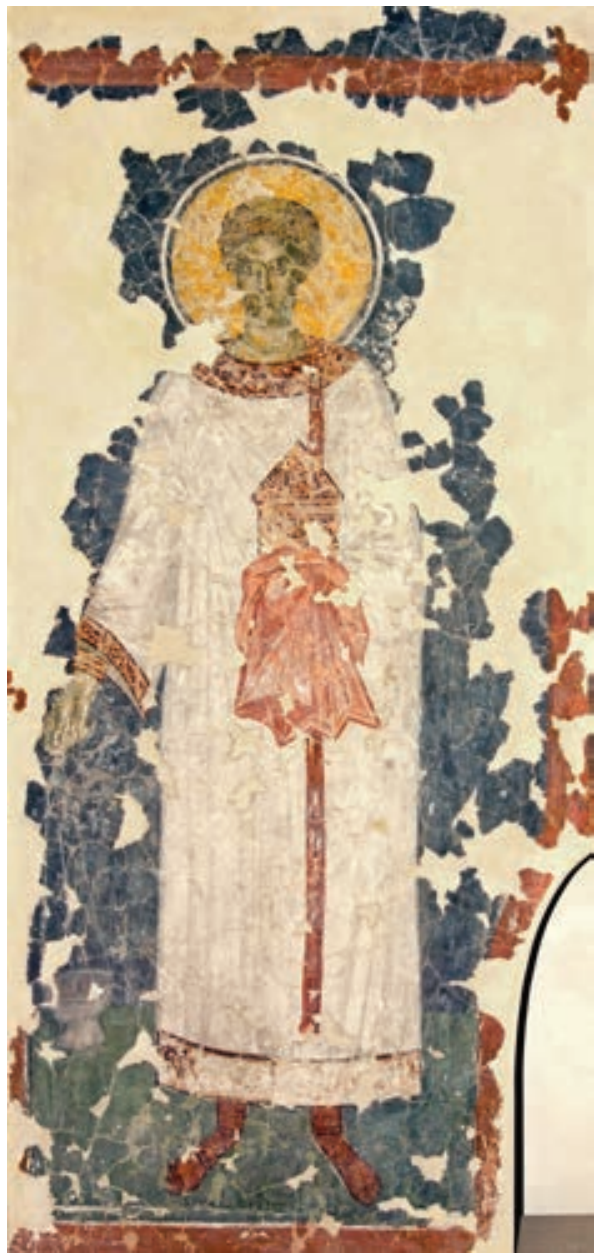

Ill. 23. St. Stephen swinging a thurible without a lid. Wall painting from the Transfiguration Church at Kovalevo. 1380. Novgorod Museum 